\title{
Modern pollution signals in sediments from Windermere, NW England, determined by micro-XRF and lead isotope analysis
}

\author{
H. Miller ${ }^{\mathrm{a}}$, I.W. Croudace ${ }^{\mathrm{a}}$, J.M. Bull ${ }^{\mathrm{a}}$, C.J. Cotterill ${ }^{\mathrm{b}}$, J.K. Dix ${ }^{\mathrm{a}}$ and R.N. Taylor ${ }^{\mathrm{a}}$. \\ a Ocean and Earth Science, University of Southampton, National Oceanography Centre, European Way, \\ Southampton, SO14 3ZH, UK \\ ${ }^{\mathrm{b}}$ British Geological Survey, Murchison House, West Mains Road, Edinburgh, EH9 3LA, UK
}

Modern pollution signals in sediments from Windermere, NW England, determined by micro-XRF and lead isotope analysis Miller, H., Croudace, I.W., Bull, J.M., Cotterill, C.J., Dix, J.K. and Taylor, R.N.. In Micro-XRF Studies of Sediment Cores: Applications of a Non-destructive Tool for the Environmental Sciences: Part III Croudace, I,W. and Rothwell, R.G. (eds.), 2015. Dordrecht, NL. Developments in Paleoenvironmental Research, 17: 423-442. doi: 10.1007/978-94-017-9849-5_16

\begin{abstract}
High resolution geochemical (Itrax micro-XRF and wavelength dispersive XRF) data, radiochronology $\left({ }^{210} \mathrm{~Pb}\right.$ and ${ }^{137} \mathrm{Cs}$ analyses) and ultra-high precision double-spike lead isotope measurements from lacustrine sediment cores are used in combination with historical research of former mining landscapes to investigate modern pollution signals in sediments from Windermere, the largest lake in the English Lake District. The sediment record suggests that while most element concentrations have been stable, there has been a significant increase since the 1930s in lead, zinc and copper concentrations. Double-spike lead isotope measurements reveal a mixture of natural lead, and three major contributory sources of anthropogenic (industrial) lead, comprising gasoline lead, coal combustion lead (from coal-fired steam ships) and lead derived from Carboniferous $\mathrm{Pb}-\mathrm{Zn}$ mineralisation (mining activities). A number of up-system sediment traps have limited the amount of mining related heavy metals entering Windermere, and as a result, periods of metal workings do not correlate with peaks in heavy metals. Increases could also be due to flood-induced metal inwash or weathering of bedrock in the catchment. Application of these non-destructive and high precision analytical techniques provides new insights into the pollutant depositional history of Windermere.
\end{abstract}

\section{Introduction}

Lacustrine sediments provide an archive of environmental change and a high resolution record of catchment level anthropogenic activity, and can be used to examine temporal changes in natural and anthropogenic trace element input. Several studies attribute the enrichment of heavy metals in lacustrine sediments to human and industrial activity during the late 19th and early 20th centuries, and more recent leaded gasoline usage (Williams, 1991; Farmer et al., 1996; Yang et al., 2002; Yang and Rose, 2005). In particular, lead isotope ratios have been increasingly used to establish the principal sources of lead pollution and yield information on geochemical origin (Gulson et al., 1994; Monna et al., 1997; Farmer et al., 1999; Hansmann and Köppel, 2000; Shepherd et al., 2009). Development of the high precision double-spike lead isotope technique (Ishizuka et al., 2003) has also led to more sensitive environmental investigations. 
Within the English Lake District, contamination of heavy metals as a result of direct human and industrial activity has been identified in several lacustrine settings. In particular, local point sources of heavy metals from mining activities have been identified within the sediments of Ullswater (Anderton et al., 1998; Kember, 2001; Grayson and Plater, 2009), Bassenthwaite (Hatfield et al., 2008; Chiverrell et al., 2012) and Brotherswater (Schillereff et al., 2013) (Fig.1). In the Windermere catchment, the historical extent of heavy metal pollution is believed to be considerable (Millward et al., 2000). Concentrations of heavy metals in sediment cores $(0.5-1 \mathrm{~m}$ long) from the South Basin have identified enriched levels of lead, zinc, copper and mercury related to anthropogenic inputs such as mining activities, denudation of land surfaces, sewage discharge, heavy industry and burning of fossil fuels (Aston et al., 1973; Hamilton-Taylor, 1979; Hamilton-Taylor, 1983).

\section{Regional Setting}

Windermere is the largest natural lake in England and is divided into a North and South Basin, separated by an area of low islands and shallow water (Fig. 1). The lake occupies a radial pre-glacial river valley and is orientated NNW to SSW, measuring c. $17 \mathrm{~km}$ in length with a maximum width of c. $1.5 \mathrm{~km}$ and depth of $62 \mathrm{~m}$ in the north. The sedimentology of the lake bed is dominated by gyttja (fine to very coarse organic rich silt) and the geomorphology is characterised by several steps and ridges, interpreted as the surface expression of recessional moraines formed during ice retreat (Miller et al., 2013; Pinson et al., 2013). The bedrock of the catchment is predominantly comprised of the Borrowdale Volcanic Group (BVG) in the north, and the Silurian (Windermere Supergroup) in the south (Mitchell, 1956; Millward et al., 2000) (Fig. 2). There are two major fault systems in the region (orientated NNW-SSE and ENE-WSW) (Postlethwaite, 1975; BGS, 1996). These faults produce kilometre-scale map offsets within the oldest orientated Silurian formations, however large offsets are not seen to the north of Windermere (Woodcock and Soper, 2006) (Fig. 2). The major fluvial inputs in the North Basin are the River Rothay, Brathay and Troutbeck, and in the South Basin the predominant inflow enters as flow from the North Basin and via Cunsey Beck (Fig. 1). The fluvial inputs drain several streams and small lakes, including Elterwater, Grasmere and Rydal Water in the north, and Esthwaite Water in the west. Land cover to the north is largely grassland on poor soils and acidified podsols, to the west is mixed woodland with improved grassland and to the east is more urban with the towns of Ambleside and Bowness-onWindermere (Pickering, 2001; Barlow et al., 2009a).

Within the Windermere catchment there are five existing sewage treatment works (STW) at Ambleside, Elterwater, Grasmere, Hawkshead and Tower Wood (Fig. 1). Wastewater entering Windermere was not treated until the opening of two STW, at Ambleside in 1886 and Beemire (near Bowness-in-Windermere) in 1888 (McGowan et al., 2012). Sewage from Beemire was subsequently diverted to a new STW at Tower Wood in 1924, which is currently the largest STW in the catchment, processing waste water from the Bowness/Windermere area. The level of nutrient enrichment and biological production in the water column has been assessed through regular monitoring since 1945, revealing a progressive change towards eutrophy (Reynolds and Irish, 2000). Increases in nutrients to the lake are attributed to a growing human population in the catchment, changes in agricultural practice and increased sewage discharge (Talling, 1999). In particular, an increase in the direct discharge of treated sewage effluents in the 1960s (due to centralisation of wastewater treatment) led to an increase in algal growth and phosphorus availability and a reduction in oxygen concentration in deep water (Reynolds and Irish, 2000; Pickering, 2001). In 1992, the introduction of a "phosphate stripping" treatment at Tower Wood and Ambleside STW led to a reduction in phosphate loading, particularly in the South Basin (Talling, 1999; Parker and Maberley, 2000). Similar findings were observed further north at Grasmere, where the onset of eutrophication is dated to 1855, analogous with the expansion of human settlement (Barker et al., 2005; Sabater and Haworth, 1995).

The Lake District has a long history of metalliferous mining and quarrying dating back to the 16th century, with some evidence for earlier activity in the 13th, 14th and 15th centuries. In the Windermere catchment, the greatest period of mineral output (for lead, copper and iron) was in the latter half of the 19th century (Pickering, 2001) and was followed by a rapid decline in the industry in 1870 due to foreign competition. There have been sporadic bursts of activity in the $20^{\text {th }}$ century, but all mining activity has now ceased (Adams, 1988, 1995). Quarrying for slate, building stone and aggregates increased in the 16th century and developed into an important 
commercial industry, particularly during the 19th century. The industry declined during late Victorian times and many small quarries closed during the early 20th century, leaving only a few commercial operators active (BGS, 2000).

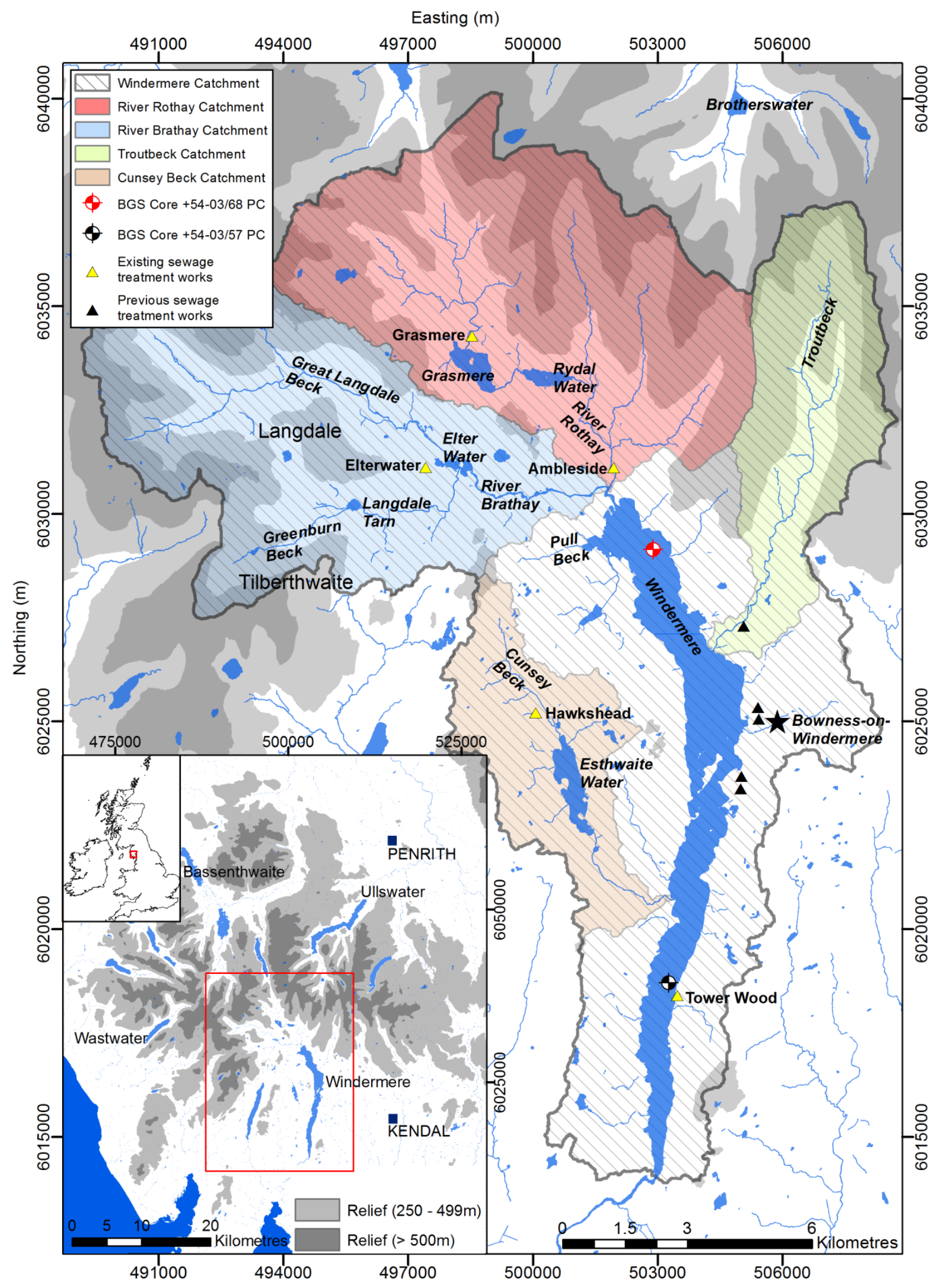


Fig. 1: Location of study area, showing the Windermere catchment, rivers, lakes, valleys, Bowness-on-Windermere (black star) and the location of existing and previous sewage treatment works and BGS sediment cores. Onshore DEM and catchment areas calculated using $5 \mathrm{~m}$ resolution NEXTMap data. Insert shows location map of the study area in relation to the Lake District and the British Isles.

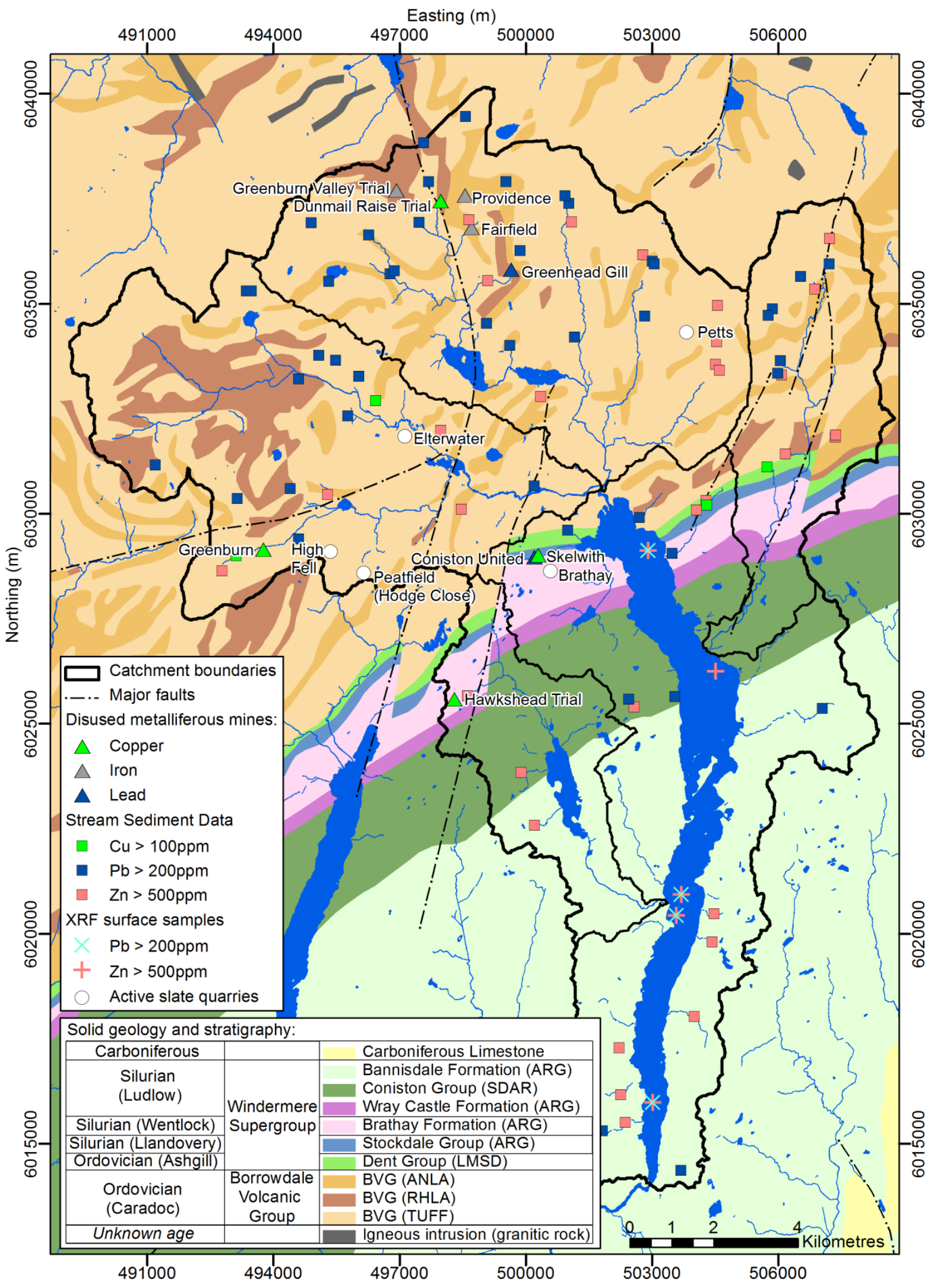


Fig. 2: Location of disused metalliferous mines and currently active slate quarries. Stream sediment and WD-XRF samples with elevated concentrations of $\mathrm{Pb}, \mathrm{Zn}$ and $\mathrm{Cu}$ are shown. Solid geology, stratigraphy and faults (BGS, 1996). BVG: Borrowdale Volcanic Group; ARG: siliciclastic argillaceous rocks; ANLA: andesitic, lava; RHLA: rhyolitic, lava; SDAR: sandstone and (subordinate) argillaceous rocks interbedded; LMSD: limestone and (subordinate) sandstone interbedded. Figure contains British Geological Survey materials @ NERC [2013].

\section{Methodology}

\section{Historical Research}

Catchment boundaries were determined using $5 \mathrm{~m}$ resolution onshore terrain data from NEXTMap Britain (a national IfSAR digital elevation database, Dowman et al., 2003) and spatial analyst tools in ArcGIS. Information on the former mining landscapes and metalliferous mining sites, output and locations within the Windermere catchment was then compiled from multiple sources, including published books and reports (Eastwood, 1921; Shaw, 1970; Postlethwaite, 1975; Adams, 1988, 1995; Tyler, 2005, 2006) and publications from local groups including the Cumbrian Amenity Trust Mining History Society (CATMHS) and the Kendal and District Mine Research Society (KDMRS). The BRITPITS Mineral Occurrence Database (MOD), the Lake District Historic Environment Record (LDHER) ${ }^{1}$, the English Heritage Archive (PastScape Record) ${ }^{2}$, the National Trust Historic Buildings, Sites and Monuments Record (HBSMR) and two additional websites ${ }^{3,4}$ were used to provide further information of mineral workings.

The BGS BRITPITS database and the LDHER were used to generate a complete list of disused quarries in the catchment. Active quarries were derived from these searches, and also the BGS BRITPITS Directory of Mines and Quarries 2010 (Cameron et al., 2010) and Millward et al., (2000). Stream sediment geochemical data were derived from BGS Geochemical Baseline Survey of the Environment (G-BASE) ${ }^{5}$. Small, first order streams were sampled from 1978 - 1980 and analysis was through direct current optical emission spectrometry (BGS, 1992; Johnson et al., 2005).

\section{Sediment Analysis}

Two piston cores from the North and South Basin were acquired in 2012 using a floating platform and piston corer designed by Uwitec ${ }^{6}$ (Fig. 1). The North Basin core +54-03/68 PC (53.7 m water depth, UTM coordinates 502900, 6029136) and South Basin core +54-03/57 PC (37.3 m water depth, 503267, 6018702) were longitudinally split (core diameter $90 \mathrm{~mm}$ ) and photographed at high resolution, with one half archived at the British Geological Survey Core Store (Keyworth, UK). U-channels were extracted from the working halves of each core and analysed using an Itrax micro-XRF core scanner at the British Ocean Sediment Core Research Facility (BOSCORF, National Oceanography Centre, UK) in accordance with the methodology detailed in Croudace et al., (2006). Itrax settings were as follows: step size $200 \mu \mathrm{m}$, counting time 30 seconds, molybdenum anode X-ray tube, XRF conditions $30 \mathrm{kV}, 50 \mathrm{~mA}$. The Itrax micro-XRF core scanner provides continuous, non-destructive, high-resolution elemental profile data, and is capable of identifying high frequency compositional changes. In addition, a number of studies (e.g. Croudace et al., 2012) have shown that Itrax elemental data (in counts) correlates well with quantitative analytical data (e.g. ICP-OES or WD-XRF). These combine to make the Itrax a unique high-resolution core scanner.

The cores were also sub-sectioned at $1 \mathrm{~cm}$ resolution and samples were freeze-dried. 35 samples from each core were analysed by wavelength dispersive X-ray fluorescence (WD-XRF) using a Philips MagiX-Pro XRF spectrometer to measure concentrations of elements of atomic mass greater than or equal to sodium. Samples were homogenised by grinding and compressed into powder pellets in accordance with the standard

\footnotetext{
${ }^{1}$ http://www.heritagegateway.org.uk

${ }^{2}$ http://www.english-heritage.org.uk/professional/archives-and-collections/nmr

${ }^{3}$ http://www. cumbria-industries.org.uk

${ }^{4}$ http://www.mine-explorer.co.uk

${ }^{5}$ http://www.bgs.ac.uk/gbase

${ }^{6}$ http://www.uwitec.at
} 
methodology (Croudace and Williams-Thorpe, 1988). A certified reference sample (BE-N, basalt, Centre de Recherches Ptrographiques et Gochimiques, France) was used as a control and calibrations previously established by analysis of 15 International Geochemical Reference samples were used. Further analysis of 16 representative lake bed sediment samples acquired in 2011 by a lightweight sediment sampler (Van Veen F42A grab) (Fig. 2) were also completed via WD-XRF analysis according to the same methodology.

Sediment accumulation rates were determined using ${ }^{210} \mathrm{~Pb}$ through the measurement of its granddaughter ${ }^{210} \mathrm{Po}$ using alpha spectrometry (Flynn, 1968). Each sample (1-3 g, $1 \mathrm{~cm}$ downcore) was spiked with ${ }^{209} \mathrm{Po}$ (nominally $50 \mathrm{mBq}$ ), digested using double acid leaching and Po separated onto silver discs by auto-deposition before counting by alpha spectrometry (100,000 seconds). A Constant Flux - Constant Sedimentation (CF:CS) model of ${ }^{210} \mathrm{~Pb}$ dating (which assumes that both the flux of unsupported ${ }^{210} \mathrm{~Pb}$ to the sediment and the sedimentation rate are constant) was used (Robbins, 1978). A Canberra well-type HPGe gamma-ray spectrometer (counting for 100,000 seconds) was used to determine the ${ }^{137} \mathrm{Cs}$ activity of samples from $0-20 \mathrm{~cm}, 29.5 \mathrm{~cm}$ and $39.5 \mathrm{~cm}$ (sampled at $1 \mathrm{~cm}$ resolution). The standard method of evaluating the $661 \mathrm{keV}$ peaks of the spectra (Ritchie and McHenry, 1990) was used, and each activity was corrected for sample mass and volume.

High precision lead isotopic abundances were also determined using a Thermo Scientific NEPTUNE Multi Collector (MC) inductively-coupled plasma mass spectrometer (ICPMS) to yield information on geochemical origin. Samples from both cores ranging from $0.5-66.5 \mathrm{~cm}$ depth $(1 \mathrm{~cm}$ downcore sampling resolution) were digested using double acid leaching followed by the isolation of lead from the matrix using AG1-X8 200-400 mesh anion exchange resin. All samples were measured with a ${ }^{208} \mathrm{~Pb}$ ion beam intensity of $>1 \times 10^{-10} \mathrm{~A}$ as an integration of $>20$ measurements, each integrating 5 seconds. Instrumental mass bias was corrected using the SBL74 ${ }^{207} \mathrm{~Pb}-{ }^{204} \mathrm{~Pb}$ double spike developed at the University of Southampton (Ishizuka et al., 2003). Pb standard NBS 981 gave results, $16.9403 \pm 27$ (2SD) for ${ }^{206} \mathrm{~Pb} /{ }^{204} \mathrm{~Pb}, 15.4973 \pm 21$ for ${ }^{207} \mathrm{~Pb} /{ }^{204} \mathrm{~Pb}$ and $36.7169 \pm 66$ for ${ }^{208} \mathrm{~Pb} /{ }^{204} \mathrm{~Pb}$. The lead isotopic standard NBS 981 was measured to assess accuracy, a procedural blank was treated in the same manner as the samples to determine possible contamination from reagents and general handling and clean laboratory techniques and high purity reagents were used to avoid contamination of samples with additional lead.

\section{Results}

\section{Mining and Quarrying}

Metalliferous mining exploited mineral (copper, haematite and lead-zinc) veins within Ordovician (BVG) rocks to the north of the Windermere catchment, particularly during the latter half of the 19th century (Fig. 2, Table 1). Copper mining took place at Greenburn, Skelwith and Hawkshead to the west of Windermere, and at Dunmail Raise Trial to the north. The largest mine was at Greenburn where five named E-W copper veins (through coarse ashes and breccias of the BVG) yielding copper pyrites and a large quantity of oxide of copper were worked to varying degrees (Postlethwaite, 1975). The low-grade ore was treated in lead lined stone tanks, by leaching the copper from the ore and then recovering by precipitation onto scrap iron (Blundell, 1994; Holland, 2000). Stream sediment geochemical data acquired in 1978 - 1980 (BGS G-BASE) identifies elevated levels of copper (above the background level of 10 - 25 ppm) near Greenburn Copper Mine, most likely derived from spoil heaps and workings (Fig. 2). Iron ore mines in the catchment exploited haematite-bearing veins within the heavily faulted BVG rocks NE of Grasmere within the River Rothay catchment (Shaw, 1970) (Fig. 2, Table 1). Providence and Fairfield mine were closed in 1877 due to low production, high transport costs and falling prices, but were later worked during the 1930s due to the high price of iron (Postlethwaite, 1975). Lead mines in the catchment worked mineral veins within the fault system at Greenhead Gill and Coniston United. The lead mine high up Greenhead Gill to the north of Grasmere was worked for lead and silver and tried by opencasts, deep shafts and short levels driven along the four E-W coursing veins. Although zinc was present in higher quantities it was not mined because it had no commercial value (Shaw, 1939). Stream sediment geochemical data in this region identifies elevated levels of lead (>200 ppm).

Slate quarrying in the Windermere catchment has taken place since the 17th century (Tyler, 2006) predominantly to the north of the catchment in the upper part of the volcaniclastic sedimentary rocks of the 
BVG which yield sea-green slate in large quantities (Postlethwaite, 1975; Millward et al., 2000). Slate quarrying is the only active extractive industry in the catchment operating on a small scale, with five quarries at Elterwater, Peatfield, High Fell, Petts and Brathay currently active (BGS BRITPITS database; Millward et al., 2000; Cameron et al., 2010) (Fig. 2). In addition to slate quarrying, small scale open-pit or surface workings extracted igneous and metamorphic rocks (from the BVG), sandstone (from Silurian siltstones and mudstones within the Coniston Group and Bannisdale Formation) and sand and gravel. Quarrying in the catchment has led to increased fine sediment supply to Windermere, particularly evident in the North Basin (Pickering, 2001; Barlow et al., 2009b).

The greatest period of metalliferous output within the Windermere catchment was in the latter half of the 19th century (Table 1). These periods of metal workings do not correspond with notable increases in heavy metals (Figs. 3 and 4). In addition, in the northern portion of the Windermere catchment, some headwater regions (which are not influenced by mining activities) have high concentrations of lead, zinc and copper in stream sediment geochemical data. This could be due to the weathering of bedrock, and it is likely that the presence of mineral veins acts as conduits for heavy metals.

\section{Sediment accumulation rates}

The CF:CS model of ${ }^{210} \mathrm{~Pb}$ dating was used to determine accumulation rates. Supported ${ }^{210} \mathrm{~Pb}$ activity in the North Basin (core +54-03/68 PC) was estimated to be 0.019 Bq/g, and a linear fit through a plot of the natural logarithm of the determined excess ${ }^{210} \mathrm{~Pb}$ activities for each sample suggests an average accumulation rate of $0.17 \mathrm{~cm} / \mathrm{yr}$ (2 S.E. $0.15-0.21 \mathrm{~cm} / \mathrm{yr}$ ). In the Lake District, the impact of the Chernobyl disaster (1968) is significant, with the input of most Chernobyl-derived Cs through direct atmospheric deposition during a few hours of intense rainfall after the incident. ${ }^{137} \mathrm{Cs}$ activity in core +54-03/68 PC was measured in order to validate the ${ }^{210} \mathrm{~Pb}$ accumulation rate over the last 49 years. At the top of the core, a peak in ${ }^{137} \mathrm{Cs}$ activity is taken to correspond to the 1986 Chernobyl incident (Ritchie and McHenry, 1990). An additional in peak in ${ }^{137} \mathrm{Cs}$ activity at a depth of $4.5 \pm 0.5 \mathrm{~cm}$ is taken to correspond to the 1963 atmospheric testing of nuclear weapons (bomb maximum) (Fig. 3). This suggests an average sediment accumulation rate of $0.17 \pm 0.02 \mathrm{~cm} / \mathrm{yr}$ from 1963 to 1986, which is consistent with the ${ }^{210} \mathrm{~Pb}$ accumulation rate.

${ }^{137} \mathrm{Cs}$ activity was not observed in the South Basin (core $+54-03 / 57 \mathrm{PC}$ ) and ${ }^{210} \mathrm{~Pb}$ results were more variable, with outlier values between $1-5 \mathrm{~cm}$ depth. Following removal of outliers, ${ }^{210} \mathrm{~Pb}$ activity was estimated to be $0.033 \mathrm{~Bq} / \mathrm{g}$ (based on observing the activity in the deepest samples where the excess $\mathrm{Pb}$ activity tends towards a baseline of zero) giving an accumulation rate of $0.14 \mathrm{~cm} / \mathrm{yr}$ (2 S.E. $0.08-0.56 \mathrm{~cm} / \mathrm{yr}$ ) (Fig. 3). The likely presence of erosion surfaces in core $+54-03 / 68$ PC and +54-03/57 PC will be discussed further in the discussion section.

\section{Heavy metal profiles}

Itrax elemental profiles in the North Basin (core +54-03/68 PC) reflect conventional WD-XRF compositional variations and show a lake catchment that has been fairly stable over the period of sediment accumulation (Fig. 3). Within the top $12 \mathrm{~cm}$ of the recovered core (69 year period) there are significant deviations from this stability. The Itrax data show a stepwise increase in lead from 1935 to 1960, and increases in lead, zinc and copper are also observed from 1960 to 1968 and 1978 to 1984 (Fig. 3). This co-variation of elemental profiles indicates a common source for these contaminants.

In the South Basin (core +54-03/57 PC), Itrax and WD-XRF concentrations of lead and copper are relatively stable over the period of sediment accumulation; however, a marked increase is observed in lead from 1935 to 1950 and in copper from 1940 to 1950 (Fig. 4). Although zinc concentrations show a similar increase, deeper in the core the Itrax zinc profile shows deviation whereas corresponding WD-XRF concentrations show a fairly stable profile (Fig. 4). This disagreement between Itrax and WD-XRF data is caused by an inter-element effect due to variations in iron (there is a negative correlation between relatively high concentrations of iron and trace concentrations of zinc). WD-XRF fundamental parameter software corrects for inter-element effects, whereas this capability is not provided in the Itrax software. 


\section{Lead isotopes}

${ }^{206} \mathrm{~Pb} /{ }^{207} \mathrm{~Pb}$ of excess lead in the North and South Basin core shows a similar profile over time (based on the sediment accumulation rates derived from ${ }^{210} \mathrm{~Pb}$ dating). The data, which has been depth shifted to compensate for loss of sediment in the top of the cores (see discussion section), reveals the oldest samples (from 1810 to 1620) have a relatively constant ${ }^{206} \mathrm{~Pb} /{ }^{207} \mathrm{~Pb}$ around 1.177 . These samples trend towards end-member ratios for early-/pre industrial sediments (Hamilton and Clifton, 1979; Croudace and Cundy, 1995). Samples ranging in age from the 1920 s to the 1840 s are characterised by a ${ }^{206} \mathrm{~Pb} /{ }^{207} \mathrm{~Pb}$ around 1.179 and trend towards end-member ratios for Carboniferous coal (Shepherd et al., 2009). Samples characterised by a low ${ }^{206} \mathrm{~Pb} /{ }^{207} \mathrm{~Pb}$ (ranging in age from 1980 to the 1920s) trend towards the isotopically distinguishable UK gasoline end-member ratio (Monna et al., 1997) (Fig. 5).

\begin{tabular}{|c|c|c|c|c|c|}
\hline Mine & Mineral & $\begin{array}{c}\text { Coordinates } \\
\text { (UTM) }\end{array}$ & Period of Operation & $\begin{array}{l}\text { Greatest period } \\
\text { mineral output }\end{array}$ & Details \\
\hline $\begin{array}{l}\text { Greenburn } \\
\text { (Great } \\
\text { Coniston } \\
\text { Mine/New } \\
\text { Coniston }\end{array}$ & Copper & $\begin{array}{l}493746 \\
6029173\end{array}$ & $\begin{array}{l}\text { 1845, evidence for 1690; } \\
\text { closed } 1942 \text { (Adams, } \\
\text { 1988, 1995; Blundell, } \\
\text { 1994) }\end{array}$ & $\begin{array}{l}1854-1861 \text { (mid } \\
19^{\text {th }} \text { century) } \\
\text { (Millward and } \\
\text { Robinson, 1974) }\end{array}$ & $\begin{array}{l}\text { Suspension in late } 19^{\text {th }} \\
\text { century, re-opened in } \\
\text { early } 20^{\text {th }} \text { century }\end{array}$ \\
\hline $\begin{array}{l}\text { Hawkshead } \\
\text { Trial }\end{array}$ & Copper & $\begin{array}{l}498289 \\
6025614\end{array}$ & c. 1830 (Tyler, 2006) & - & Small copper trial \\
\hline Skelwith & Copper & $\begin{array}{l}500290 \\
6029024\end{array}$ & $\begin{array}{l}\text { Opened } 1540 \text { (English } \\
\text { Heritage Archive), } \\
\text { closed } 1901\end{array}$ & $1850 \mathrm{~s}$ & $\begin{array}{l}\text { Post Medieval copper } \\
\text { mine }\end{array}$ \\
\hline $\begin{array}{l}\text { Dunmail } \\
\text { Raise Trial }\end{array}$ & Copper & $\begin{array}{l}499665 \\
6035813\end{array}$ & $\begin{array}{l}\text { c. } 1920 \text { (Adams, 1988, } \\
\text { 1995; Tyler, 2005, } \\
\text { 2006). }\end{array}$ & - & $\begin{array}{l}\text { Good quality copper } \\
\text { ore, not in commercial } \\
\text { quantities }\end{array}$ \\
\hline $\begin{array}{l}\text { Providence } \\
\text { (Tongue } \\
\text { Gill Iron } \\
\text { Mines) } \\
\text { Fairfield }\end{array}$ & Iron & $\begin{array}{l}4986619 \\
6037515\end{array}$ & $\begin{array}{l}\text { Providence and } \\
\text { Fairfield: start unknown, } \\
\text { although mine supplied } \\
\text { ore to the smelter in } \\
\text { Langdale around } 1700 ; \\
\text { re-opened in } 1873 \text {, } \\
\text { closed in } 1877 \text { (Tyler, } \\
\text { 2005). Re-opened in } \\
\text { 1930s (Postlethwaite, } \\
\text { 1975). }\end{array}$ & $\begin{array}{l}\text { Providence and } \\
\text { Fairfield: early } \\
17^{\text {th }} \text { century, } \\
\text { revival } 1874 \text { - } \\
1876 \text { (Shaw, } \\
1970 \text { ) }\end{array}$ & $\begin{array}{l}\text { Providence and } \\
\text { Fairfield: ancient iron } \\
\text { ore mines }\end{array}$ \\
\hline $\begin{array}{l}\text { Greenburn } \\
\text { Valley Trial }\end{array}$ & Iron & $\begin{array}{l}496900 \\
6037679\end{array}$ & $1880 \mathrm{~s}$ & - & $\begin{array}{l}\text { Small trial (Tyler, } \\
\text { 2006) }\end{array}$ \\
\hline $\begin{array}{l}\text { Greenhead } \\
\text { Gill } \\
\text { (Grasmere } \\
\text { Lead Mine) }\end{array}$ & Lead & $\begin{array}{l}\text { 499665, } \\
6035813\end{array}$ & $\begin{array}{l}\text { Opened 1564, closed } \\
1573 \text { (Shaw, 1970; } \\
\text { Tyler, 2005). Re-worked } \\
\text { in 1870s but soon } \\
\text { abandoned (KDMRS } \\
\text { newsletter, 1983, Tyler } \\
\text { 2005, 2006) }\end{array}$ & - & $\begin{array}{l}\text { Extensive account, } \\
\text { including production } \\
\text { data (Tyler, 2005) }\end{array}$ \\
\hline $\begin{array}{l}\text { Coniston } \\
\text { United }\end{array}$ & Lead & $\begin{array}{l}500196 \\
6028966\end{array}$ & $\begin{array}{l}\text { c. } 1853 \text { (Adams, 1988, } \\
1995 \text { ) }\end{array}$ & - & $\begin{array}{l}\text { Group of trials, two } \\
\text { levels, little } \\
\text { mineralisation }\end{array}$ \\
\hline
\end{tabular}


Table 1: Disused copper, lead and iron mines in the Windermere catchment.
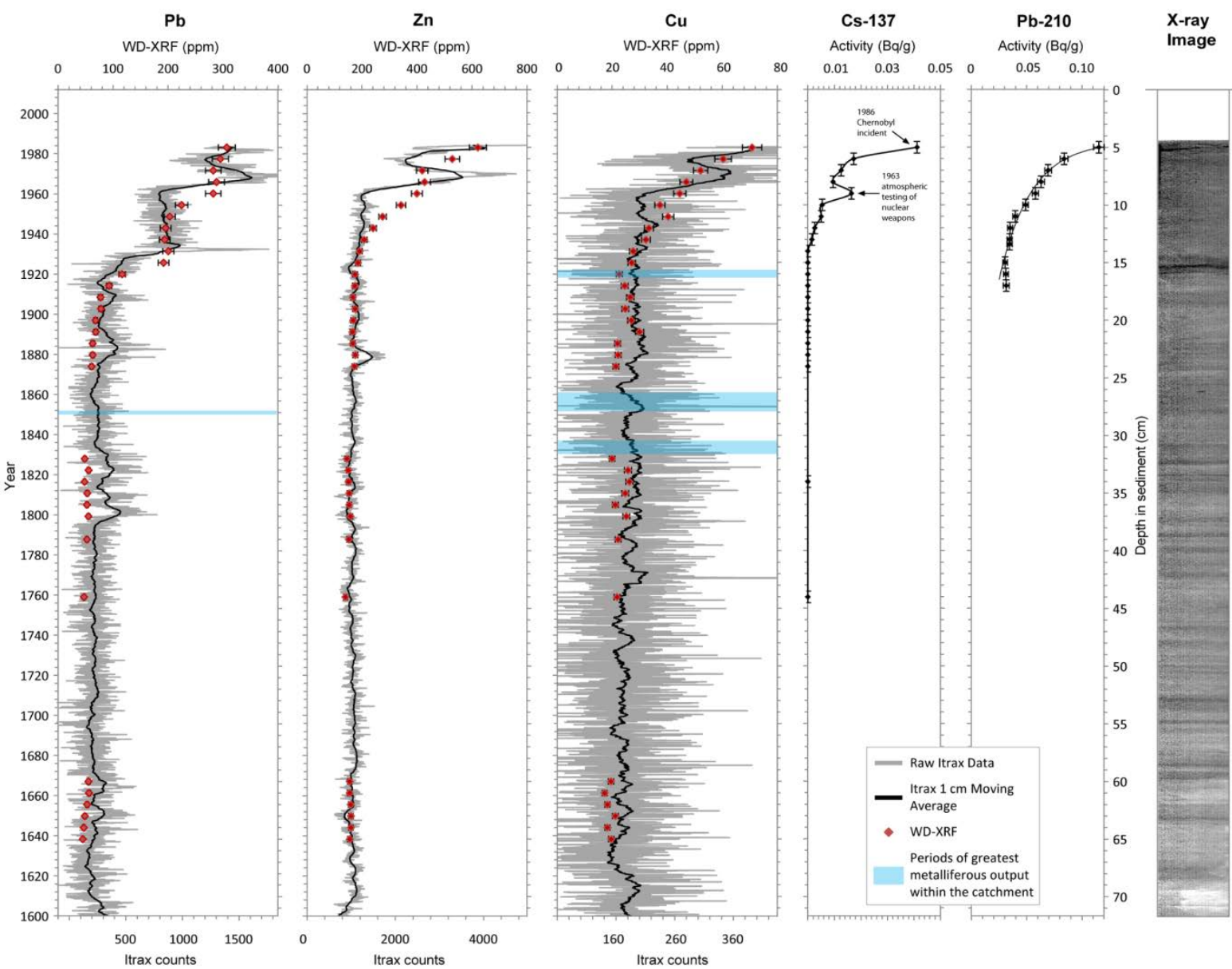

Fig 3: Elemental profiles, ${ }^{137} \mathrm{Cs}$ activity and total ${ }^{210} \mathrm{~Pb}$ activity in core $+54-03 / 68 \mathrm{PC}$ (North Basin). Periods of metalliferous output are highlighted, continuous lines show Itrax peak areas, points show concentrations determined from sub-samples using WD-XRF and the X-ray image is from the Itrax core scanner. $4.52 \mathrm{~cm}$ is added to the sample depth to compensate for loss of sediment in the top of the core. 


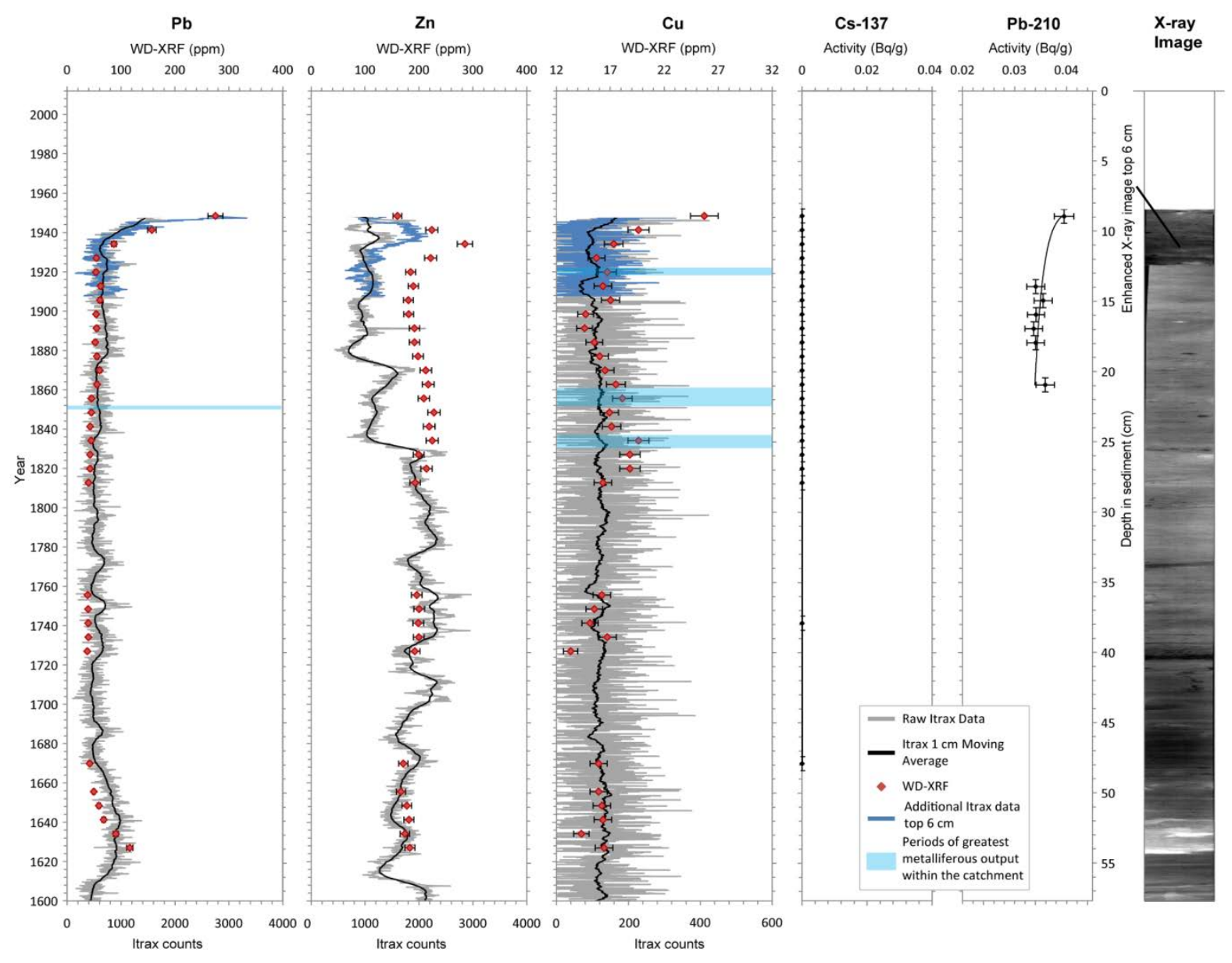

Fig 4: Elemental profiles, ${ }^{137} \mathrm{Cs}$ activity and total ${ }^{210} \mathrm{~Pb}$ activity in core $+54-03 / 57 \mathrm{PC}$ (South Basin). Periods of metalliferous output are highlighted, continuous lines show Itrax peak areas, points show concentrations determined from sub-samples using WD-XRF and the X-ray image is from the Itrax core scanner. $8.4 \mathrm{~cm}$ is added to the sample depth to compensate for loss of sediment in the top of the core. 


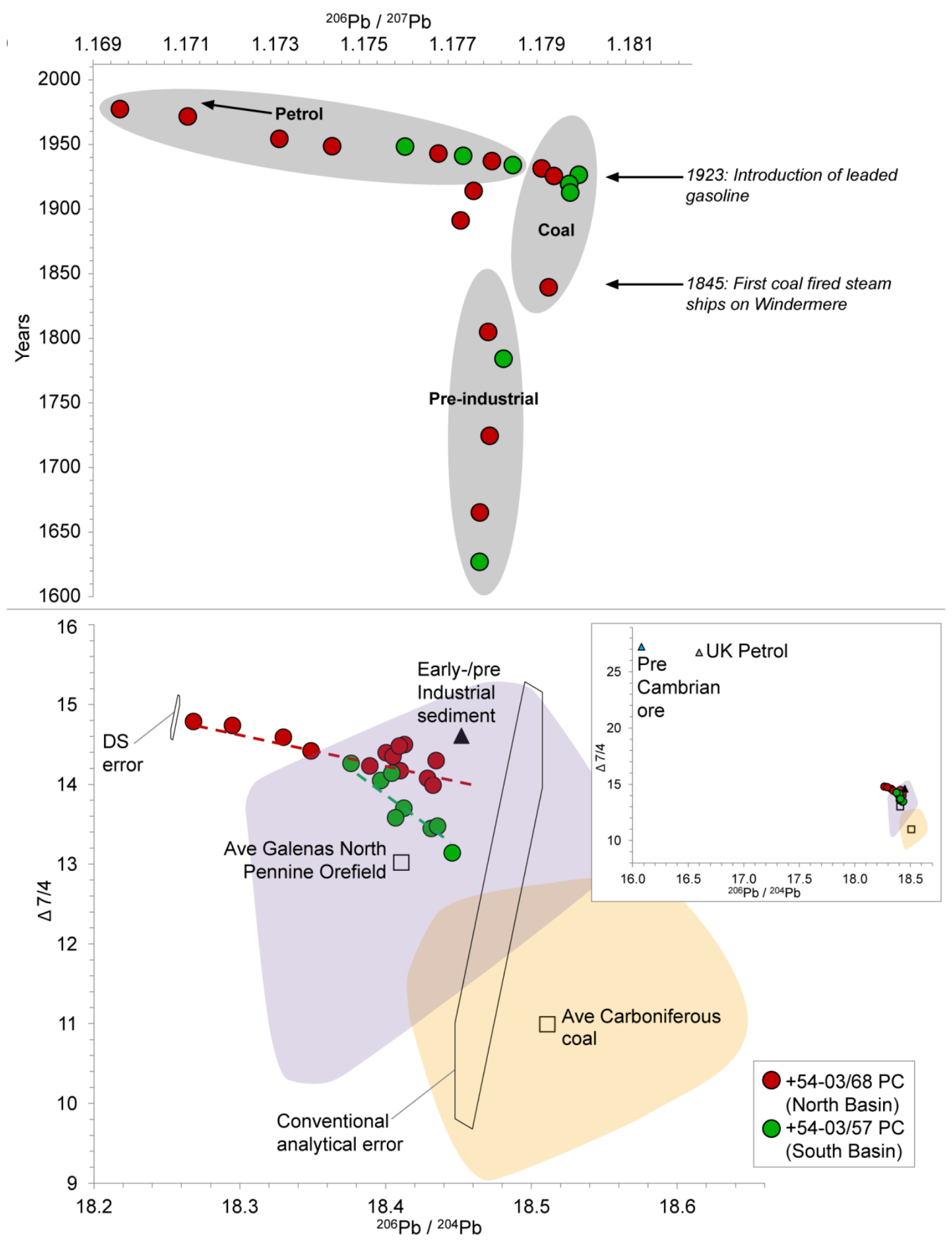

Fig 5: Upper panel: lead isotope ratios $\left({ }^{206} \mathrm{~Pb} /{ }^{207} \mathrm{~Pb}\right)$ over time. Lower panel: $\Delta 7 / 4$ versus ${ }^{206} \mathrm{~Pb} /{ }^{204} \mathrm{~Pb}$ with double-spike and conventional analytical errors for comparison, average (mean) end-member ratio for pre-/early industrial sediment and Carboniferous coal and galena ratios (derived by conventional lead isotope measurement techniques). Insert shows Pre-Cambrian ore ratios and UK gasoline end-member ratio. See Table 2 for details. 


\begin{tabular}{|c|c|c|c|c|c|c|c|}
\hline Core & $\begin{array}{l}\text { Depth in } \\
\text { core }(\mathrm{cm})\end{array}$ & ${ }^{206} \mathrm{~Pb} /{ }^{204} \mathrm{~Pb}$ & \pm & ${ }^{207} \mathrm{~Pb} /{ }^{204} \mathrm{~Pb}$ & \pm & ${ }^{208} \mathrm{~Pb} /{ }^{204} \mathrm{~Pb}$ & \pm \\
\hline \multirow{14}{*}{$\begin{array}{c}+54-03 / 68 \text { PC } \\
\text { North Basin }\end{array}$} & 6.02 & 18.2682 & 12 & 15.6192 & 11 & 38.2692 & 35 \\
\hline & 7.02 & 18.2949 & 39 & 15.6216 & 38 & 38.3002 & 117 \\
\hline & 10.02 & 18.3299 & 9 & 15.6239 & 9 & 38.3364 & 27 \\
\hline & 11.02 & 18.3488 & 12 & 15.6242 & 12 & 38.3578 & 37 \\
\hline & 12.02 & 18.3892 & 20 & 15.6267 & 19 & 38.4011 & 60 \\
\hline & 13.02 & 18.4100 & 27 & 15.6283 & 25 & 38.4247 & 79 \\
\hline & 14.02 & 18.4288 & 13 & 15.6294 & 13 & 38.4484 & 39 \\
\hline & 15.02 & 18.4325 & 12 & 15.6290 & 12 & 38.4501 & 37 \\
\hline & 17.02 & 18.4051 & 20 & 15.6296 & 19 & 38.4174 & 61 \\
\hline & 21.02 & 18.4004 & 11 & 15.6296 & 11 & 38.4097 & 33 \\
\hline & 30.02 & 18.4346 & 11 & 15.6323 & 10 & 38.4747 & 32 \\
\hline & 36.02 & 18.4129 & 10 & 15.6319 & 10 & 38.4303 & 30 \\
\hline & 45.02 & 18.3226 & 10 & 15.5548 & 9 & 38.2214 & 28 \\
\hline & 60.02 & 18.4094 & 19 & 15.6314 & 18 & 38.4289 & 57 \\
\hline \multirow{9}{*}{$\begin{array}{c}+54-03 / 57 \text { PC } \\
\text { South Basin }\end{array}$} & 8.9 & 18.3762 & 12 & 15.6256 & 11 & 38.3754 & 35 \\
\hline & 9.9 & 18.3968 & 9 & 15.6257 & 8 & 38.3906 & 25 \\
\hline & 10.9 & 18.4121 & 18 & 15.6239 & 17 & 38.4089 & 54 \\
\hline & 11.9 & 18.4356 & 22 & 15.6242 & 21 & 38.4394 & 66 \\
\hline & 12.9 & 18.4453 & 42 & 15.6218 & 14 & 38.4388 & 42 \\
\hline & 13.9 & 18.4313 & 37 & 15.6234 & 35 & 38.4311 & 109 \\
\hline & 31.9 & 18.4067 & 15 & 15.6221 & 15 & 38.4125 & 45 \\
\hline & 53.9 & 18.4042 & 29 & 15.6274 & 28 & 38.4025 & 87 \\
\hline & 74.9 & 18.3075 & 9 & 15.5236 & 9 & 38.1420 & 28 \\
\hline \multirow{2}{*}{ End Member } & \multirow{2}{*}{\multicolumn{2}{|c|}{ Source }} & & osition of & \multirow{2}{*}{\multicolumn{3}{|c|}{ Reference }} \\
\hline & & & & ${ }^{207} \mathrm{~Pb} /{ }^{204}$ & & & \\
\hline
\end{tabular}

$\begin{array}{cccc}\begin{array}{c}\text { Carboniferous } \\ \text { coal }\end{array} & \begin{array}{c}\text { Durham } \\ \text { Northumberland } \\ \text { coalfield }(\mathrm{n}=11)\end{array} & 18.51 & 15.60\end{array} \quad$ Shepherd et al., (2009)

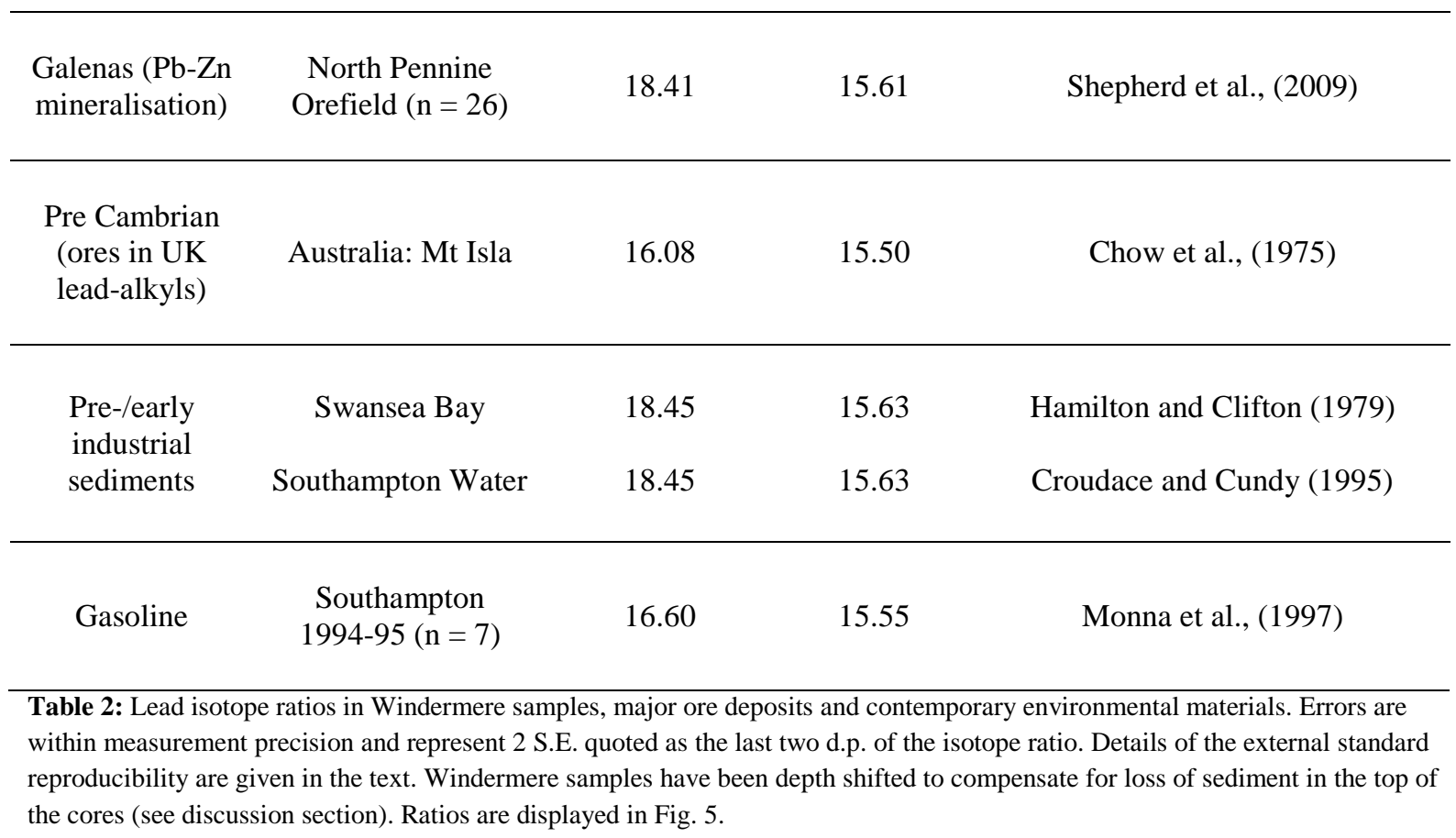




\section{Discussion}

A number of studies have dated recent sediments in Windermere and other lakes in the catchment (Aston et al., 1973; Pennington et al., 1973; Pennington et al., 1976; Appleby et al., 1991; Appleby et al., 2003; Barker et al., 2005). In the North Basin, ${ }^{210} \mathrm{~Pb}$ dates from a 1997 mini-core (located c. $600 \mathrm{~m} \mathrm{SW}$ of core +54-03/68 PC) suggest a mean accumulation rate of approximately $0.18 \mathrm{~cm} / \mathrm{yr}$ (Appleby, 2008). This is in agreement (within the estimated uncertainty) with the accumulation rate of $0.17 \mathrm{~cm} / \mathrm{yr}$ determined for core $+54-03 / 68 \mathrm{PC}$. Appleby (2008) also identified two peaks in the ${ }^{137} \mathrm{Cs}$ record at $4.5 \mathrm{~cm}$ and $10.5 \mathrm{~cm}$ related to the 1986 Chernobyl incident and the 1963 bomb maximum. In core $+54-03 / 68$ PC, two peaks in ${ }^{137}$ Cs activity are also identified: at the top of the core (related to the 1986 Chernobyl incident) and at $4.5 \pm 0.5 \mathrm{~cm}$. This suggests a loss of at least $4.52 \mathrm{~cm}(0.17 \mathrm{~cm} / \mathrm{yr}$ over 26 years) of sediment from the top of the core (Fig. 3). In the South Basin, outlier

${ }^{210} \mathrm{~Pb}$ values and the absence of ${ }^{137} \mathrm{Cs}$ suggests a loss of at least 60 years of accumulation (initial input of ${ }^{137} \mathrm{Cs}$ estimated to be 1952, related to atmospheric nuclear weapons testing). This suggests a loss of at least $8.4 \mathrm{~cm}$ $\left(0.14 \mathrm{~cm} / \mathrm{yr}\right.$ over 60 years) of sediment from the top of the core (Fig. 4). The ${ }^{210} \mathrm{~Pb}$ accumulation rates are valid in the surface sediments; however, it is important to note that the accumulation rate may not be representative at depth, and therefore the depth in the core and the extrapolated chronology are displayed for comparison (Figs. 3 and 4).

In the North Basin, Itrax elemental profiles and WD-XRF concentrations identify an increase in lead concentration from 1935 to 1960, and a significant increase from 1960 to 1968. A similar increase is observed in the South Basin from 1935 to 1950 (Figs. 3 and 4). These increases are most likely the result of increased industrialisation, urbanisation and road traffic following the introduction and use of $\left({ }^{206} \mathrm{~Pb}\right.$-depleted) leaded gasoline post-1923. Within the UK, this led to a dramatic increase in atmospheric lead emissions, particularly during the 1960s and 1970s (Farmer et al., 1996; Komárek et al., 2008; Shepherd et al., 2009). High-precision lead isotopes (measured by double spike, errors $< \pm 0.002 \%$ ) also reveal a significant decline in ${ }^{206} \mathrm{~Pb} /{ }^{207} \mathrm{~Pb}$ from the 1920s to 1980 (attributable to the use of alkyl-leaded fuel), demonstrating a significant anthropogenic input of lead in recent sediments (Fig. 5). In addition, $\Delta 7 / 4$ (calculated relative to the Northern Hemisphere Reference Line; Hart, 1984) trends towards the UK gasoline end-member ratio which suggests leaded gasoline is a common source of lead in recent sediments (Fig. 5, lower panel).

The isotopic character of lead changes with depth, and samples ranging in age from the 1840s to the 1920s trend towards the end-member ratio for Carboniferous coal (Shepherd et al., 2009) (Fig. 5). In Windermere, the most likely source of Carboniferous coal is coal-fired steam ships, which operated on the lake from 1845 onwards (Pattinson, 1981; Pickering, 2001; McGowan et al., 2012). Expansion in the use of these boats took place following arrival of the railway in Windermere in 1847 and Lakeside in 1869, and also the introduction of a steam cargo service in 1872 (Pattinson, 1981). From the 1920s onwards, motor vehicles were common and the age of steam on Windermere gradually came to a close. The decline observed in ${ }^{206} \mathrm{~Pb} /{ }^{207} \mathrm{~Pb}$ from the $1920 \mathrm{~s}$ to 1980 is most likely due to the end of coal-fired steamer operation on the lake and the introduction and use of leaded gasoline. Coal combustion (associated with the Industrial Revolution) also represents another possible source of Carboniferous coal.

Analysis of $\Delta 7 / 4$ also identifies components of natural lead and galena ore from mineral veins, most likely derived from the discharge of lead-rich waste from abandoned mines (Carboniferous Pb-Zn mineralisation) (Fig. 5, lower panel). Natural lead is derived from surface weathering (particularly in headwater regions not influenced by mining activities), soil erosion and $\mathrm{Pb}-\mathrm{Zn}$ mineralisation. The elevated levels of lead in Windermere are therefore considered to be a mixture of natural lead, and three major components of anthropogenic lead (gasoline lead, coal combustion lead and lead derived from Carboniferous $\mathrm{Pb}-\mathrm{Zn}$ mineralisation).

Copper concentrations also show an increase from 1960 to 1968 and 1978 to 1984 in the North Basin and from 1940 to 1950 in the South Basin (Figs. 3 and 4). Lead and zinc concentrations (particularly in the North Basin) show similar variations, suggesting a co-variance of these contaminants and a common source. To the north of Windermere, a number of up-system sediment traps (e.g. Grasmere, Elterwater and Langdale Tarn) (Fig. 2) have 
limited the amount of mining related heavy metals entering Windermere. As a result, periods of metal workings do not correlate with peaks in mining related heavy metals due to the trapping efficiency of these up-system lakes. For example, at Elterwater (downstream from Greenburn Mine), copper contamination is recorded in sediments (Pickering, 2001), demonstrating the effectiveness of up-system sediment traps. Copper increases in the 1940s and 1960s could also be due to flood-induced metal inwash after the cessation of mining (similar to findings in other upland regions of Britain; Kelly, 1991), or weathering of bedrock in the catchment. Increases in zinc could also be due to anthropogenic activity within the catchment, in the form of processed waste and human sewage inputs. In particular, an increase in direct discharge of treated sewage effluents in the 1960s corresponds with an increase in zinc at this time.

\section{Conclusions}

This study investigates the pollutant deposition of Windermere and the surrounding catchment using highresolution Itrax analysis (validated against WD-XRF), radiochronology $\left({ }^{210} \mathrm{~Pb}\right.$ and ${ }^{137} \mathrm{Cs}$ ) and double spike lead isotopes (offering ten times the precision of the conventional single spike method). Application of these nondestructive and high precision analytical techniques has enabled determination of the timing and scale of anthropogenic inputs to Windermere, and demonstrates the effectiveness of an integrated approach when investigating pollution signals in lacustrine environments. 


\section{References}

Adams, J., 1988: Mines of the Lake District Fells. Dalesman Books.

Adams, J., 1995: Mines of the Lake District Fells, 2nd Edition. Dalesman Publishing Company.

Anderton, J., Haworth, E. Y., Horne, D. J., and Wray, D. S., 1998: Environmental impacts of lead mining in the Ullswater catchment (English Lake District): dam failures and flooding. Bennett, M. R., and Doyle, P. Eds., Issues in environmental geology: a British perspective. The Geological Society, 226-242.

Appleby, P., Richardson, N., and Nolan, P., 1991: ${ }^{241}$ am dating of lake sediments. Hydrobiologia 214(1), 35-42.

Appleby, P. G., Haworth, E. Y., Michel, H., Short, D. B., Laptev, G., and Piliposian, G. T., 2003: The transport and mass balance of fallout radionuclides in Blelham Tarn, Cumbria (UK). Journal of Paleolimnology 29, 459-473.

Appleby, P., 2008: Three decades of dating recent sediments by fallout radionuclides: a review. The Holocene 18(1), 83-93.

Aston, S. R., Bruty, D., Chester, R., and Padgham, R. C., 1973: Mercury in Lake Sediments: a Possible Indicator of Technological Growth. Nature 241(5390), 450-451.

Barker, P. A., Pates, J. M., Payne, R. J., and Healey, R. M., 2005: Changing nutrient levels in Grasmere, English Lake District, during recent centuries. Freshwater Biology 50(12), 1971-1981.

Barlow, D., Harris, E., and McFarlane, A., 2009a: Windermere Fluvial Audit. Report A: Catchment Scale Geomorphology Technical Report. Report to Environment Agency North West Region prepared by JACOBS Engineering UK Ltd. Tech. rep.

Barlow, D., Harris, E., and McFarlane, A., 2009b: Windermere Fluvial Audit. Report B: Catchment Action Plan. Report to Environment Agency North West Region prepared by JACOBS Engineering UK Ltd. Tech. Rep.

Blundell, D. J., 1994: Greenburn or Great Coniston Copper Mine Little Langdale. A Collected History. In The Mine Explorer, Cumbria Amenity Trust Mining History Society, 4, 76-80.

British Geological Survey, 1992: Regional geochemistry of the Lake District and adjacent areas.

British Geological Survey, 1996: Ambleside. England and Wales Sheet 38. Solid Geology 1:50,000. Keyworth, Nottingham.

British Geological Survey, 2000: Geology of the Ambleside district. The Stationary Office, London.

Cameron, D. G., Idoin, N. E., Brown, T. J., Patton, M. A. G., McGinn, C., and Mankelow, J. M., 2010: Directory of Mines and Quarries. British Geological Survey, 9th Edition.

Chiverrell, R. C., Sear, D., Dearing, J., Warburton, J., Schillereff, D., and Croudace, I. W., 2012: Farming, Mining and Extreme Floods: Impacts of accelerated sediment flux to Bassenthwaite Lake, International Palaeolimnology Conference (IPS2012), August 21-24th, Glasgow SECC.

Chow, T. J., Snyder, C. B., and Earl, J. L., 1975: Isotope ratios of lead as pollutant source indicators. In: Isotope ratios as pollutant source and behaviour indicators. IAEA, Vienna, 95-108.

Croudace, I. W., Williams-Thorpe, O., 1988: A low dilution, wavelength-dispersive x-ray fluorescence procedure for the analysis of archaeological rock artefacts. Archaeometry 30(2), 227-236.

Croudace, I. W., and Cundy, A. B., 1995: Heavy metal and hydrocarbon pollution in recent sediments from Southampton water, Southern England: A geochemical and isotopic study. Environmental Science \& Technology 29, 1288-1296.

Croudace, I. W., Rindby, A., and Rothwell, R., 2006: ITRAX: description and evaluation of a new multi-function X-ray core scanner. Rothwell, R. Ed., New Techniques in Sediment Core Analysis. Geological Society Special Publication 267, 51-63.

Croudace, I. W., Warwick, P. E., and Morris, J. E., 2012: Evidence for the preservation of technogenic tritiated organic compounds in an estuarine sedimentary environment. Environ. Sci. Technol. 46(11), 5704-5712.

Dowman, I., Balan, P., Renner, K., and Fischer, P., 2003: An Evaluation of Nextmap Terrain Data in the Context of UK National Datasets. Tech. rep. 
Eastwood, T., 1921: Memoirs of the Geological Survey. Special reports on the mineral resources of Great Britain: The lead and zinc ores of the Lake District. Vol. 22.

Farmer, J. G., Eades, L. J., Mackenzie, A. B., Kirika, A., and Bailey-Watts, T. E., 1996: Stable Lead Isotope Record of Lead Pollution in Loch Lomond Sediments since 1630 A.D. Environmental Science \& Technology., 30(10), 3080-3083.

Farmer, J. G., Eades, L. J., and Graham, M. C., 1999: The lead content and isotopic composition of British coals and their implications for past and present releases of lead to the UK environment. Environmental Geochemistry and Health 21(3), 257-272.

Flynn, W. W., 1968: Determination of low levels of polonium-210 in environmental materials. Analytica Chimica Acta 43, 221227.

Grayson, R. P., and Plater, A. J., 2009: A lake sediment record of Pb mining from Ullswater, English Lake District, UK. Journal of Paleolimnology 42(2), 183-197.

Gulson, B. L., Mizon, K. J., Law, A. J., Korsch, M. J., Davis, J. J., and Howarth, D., 1994: Source and pathways of lead in humans from the broken hill mining community; an alternative use of exploration methods. Economic Geology 89(4), 889-908.

Hamilton-Taylor, J., 1979: Enrichments of zinc, lead, and copper in recent sediments of Windermere, England. Environmental Science \& Technology 13(6), 693-697.

Hamilton, E. I., and Clifton, R. J., 1979: Isotopic abundances of lead in estuarine sediments, Swansea Bay, Bristol Channel. Estuarine and Coastal Marine Science 8(3), 271-278.

Hamilton-Taylor, J., 1983: Heavy metal enrichments in the recent sediments of six lakes in northwest England. Environmental Technology Letters 4, 115-122.

Hansmann, W., and Köppel V., 2000: Lead-isotopes as tracers of pollutants in soils. Chemical Geology 171(1-2), 123-144.

Hart, S. R., 1984: A large-scale isotope anomaly in the Southern Hemisphere mantle. Nature, 309, 753-757.

Hatfield, R. G., Maher, B. A., Pates, J. M., and Barker, P. A., 2008: Sediment dynamics in an upland temperate catchment: changing sediment sources, rates and deposition. Journal of Paleolimnology 40(4), 1143-1158.

Holland, E. G., 2000: Coniston Copper Mines: A Field Guide to the Mines in the Copper Ore Field at Coniston in the English Lake District. Cicerone Press.

Ishizuka, O., Taylor, R. N., Milton, J. A., Nesbitt, R. W., 2003: Fluid-mantle interaction in an intra-oceanic arc: constraints from high-precision $\mathrm{Pb}$ isotopes. Earth and Planetary Science Letters 211, 221-236.

Johnson, C. C., Breward, N., Ander, E. L., and Ault, L., 2005: G-BASE: Baseline geochemical mapping of Great Britain and Northern Ireland. Geochemistry: Exploration, Environment, Analysis 5(4), 347-357.

Kelly, M., 1991: Mining and the Freshwater Environment. Elsevier Applied Science.

Kember, H. M., 2001: A study of metal contamination of sediments within Lake Ullswater and the Glenridding Beck catchment. Undergraduate Dissertation, Department of Environmental Science, University of Lancaster.

Komárek, M., Ettler, V., Chrastný, V., Mihaljevic, M., 2008: Lead isotopes in environmental sciences: A review. Environment International 34(4), 562 - 577.

McGowan, S., Barker, P., Haworth, E. Y., Leavitt, P. R., Maberly, S. C., and Pates, J., 2012: Humans and climate as drivers of algal community change in Windermere since 1850. Freshwater Biology 57(2), 260-277.

Miller, H., Bull, J. M., Cotterill, J. C., Dix, J. K., Winfield, I. J., Kemp, A. E. S., and Pearce, R. B., 2013: Lake bed geomorphology and sedimentary processes in glacial lake Windermere, UK. Journal of Maps 9(2), 299-312.

Millward, R. and Robinson, A., 1974: The Regions of Britain: The Lake District. Eyre Methuen.

Millward, D., Johnson, E. W., Beddoe-Stephens, B., Young, B., Kneller, B. C., Lee, M. K., and Fortey, N. J., 2000: British Geological Survey: Geology of the Ambleside district. Memoir for 1:50 000 Geological Sheet 38 (England and Wales). The Stationary Office, London.

Mitchell, G. H., 1956: The geological history of the Lake District. Proceedings of the Yorkshire Geological Society 30, 407-463. 
Monna, F., Lancelot, J., Croudace, I. W., Cundy, A. B., and Lewis, J. T., 1997: Pb isotopic composition of airborne particulate material from France and the southern United Kingdom: implications for Pb pollution sources in urban areas. Environ Science \& Technology 31, 2277-86.

Parker, J. E., and Maberly, S. C., 2000: Biological response to lake remediation by phosphate stripping: control of Cladophora. Freshwater Biology 44, 303-309.

Pattinson, G. H., 1981: The Great Age of Steam on Windermere. The Windermere Nautical Trust.

Pennington, W., Cambray, R. S., and Fisher, E. M., 1973: Observations on Lake Sediments using Fallout ${ }^{137}$ Cs as a Tracer. Nature 242, 324-326.

Pennington, W., Cambray, R. S., Eakins, J. D., and Harkness, D. D., 1976: Radionuclide dating of the recent sediments of Blelham Tarn. Freshwater Biology 6(4), 317-331.

Pickering, A. D., 2001: Windermere: restoring the health of England's largest lake. Freshwater Biological Association, Ambleside Special Publication No. 11.

Pinson, L. J. W., Vardy, M. E., Dix, J. K., Henstock, T. J., Bull, J. M., and Maclachlan, S. E., 2013: Deglacial history of glacial lake Windermere, UK: implications for the central British and Irish Ice Sheet. Journal of Quaternary Science 28(1), 83-94.

Postlethwaite, J., 1975: Postlethwaite’s Mines and mining in the English Lake District. Michael Moon, Beckermet Cumbria.

Reynolds, C. S., Irish, A. E., 2000: The phytoplankton of Windermere (English Lake District). Freshwater Biological Association.

Ritchie, J. C., and McHenry, J. R., 1990: Application of radioactive fallout cesium-137 for measuring soil erosion and sediment accumulation rates and patterns: A review. Journal of Environmental Quality 19(2), 215-233.

Robbins, J. A., 1978: Geochemical and geophysical applications of radioactive lead isotopes. Nriagu, J. O. Ed., Biochemistry of Lead. Elsevier, Amsterdam, 285-393.

Sabater, S., and Haworth, E. Y., 1995: An assessment of recent trophic changes in Windermere South Basin (England) based on diatom remains and fossil pigments. Journal of Paleolimnology 14(2), 151-163.

Schillereff, D., Chiverrell, R., Macdonald, N., Hooke, J., 2013: A multi-proxy lake sediment record of recent anthropogenic influence on catchment processes from Brotherswater, northwest England. Oral presentation at European Geosciences Union General Assembly 2013, 7 - 12 April 2013, Vienna, Austria. Session: Landscape in the Anthropocene: state of the art and future directions.

Shaw, W. T., 1939: Elizabethan Mining: An account of a visit paid to an old lead mine near Grasmere, Lake District.

Shaw, W. T., 1970: Mining in the Lake Counties. Dalesman, Clapham.

Shepherd, T. J., Chenery, S. R., Pashley, V., Lord, R. A., Ander, L. E., Breward, N., Hobbs, S. F., Horstwood, M., Klinck, B. A., and Worrall, F., 2009: Regional lead isotope study of a polluted river catchment: River Wear, Northern England, UK. Science of the Total Environment 407(17), 4882-4893.

Talling, J. F., 1999: Some English lakes as diverse and active ecosystems: a factual summary and source book. Freshwater Biological Association, Far Sawrey, Ambleside, Cumbria, UK.

Tyler, I., 2005: Thirlmere Mines and The Drowning of The Valley. Blue Rock Publications.

Tyler, I., 2006: The Lakes and Cumbria Mines Guide. Blue Rock Publications.

Yang, H. D., Rose, N. L., Battarbee, R. W., and Boyle, J. F., 2002: Mercury and lead budgets for Lochnagar, a Scottish mountain lake and its catchment. Environmental Science \& Technology 36(7-8), 1383-1388.

Yang, H. D., and Rose, N., 2005: Trace element pollution records in some UK lake sediments, their history, influence factors and regional differences. Environment International 31(1), 63-75.

Williams, T., 1991: A sedimentary record of the deposition of heavy metals and magnetic oxides in the Loch Dee basin, Galloway, Scotland, since c. AD 1500. The Holocene 1(2), 142-150. 
Woodcock, N. H., and Soper, N. J., 2006: The Acadian Orogeny: the mid-Devonian phase of deformation that formed slate belts in England and Wales. Benchley, P. J., and Rawson, F. Eds., The Geology of England and Wales, 2nd Edition. The Geological Society. 